\title{
Arahan Adaptasi Kawasan Rawan Tanah Longsor dalam Mengurangi Kerentanan Masyarakat di KSN Merapi Kabupaten Sleman
}

\author{
Adjie Pamungkas ${ }^{1}$ \\ Novia Destriani ${ }^{2}$ \\ ${ }^{1}$ Urban and Regional Planning Department, Institut Teknologi Sepuluh Nopember, Indonesia \\ adjieku@gmail.com
}

\begin{abstract}
ABSTRAK
Meningkatnya potensi bencana tanah longsor dalam Kawasan Strategis Nasional (KSN) Gunung Merapi Kabupaten Sleman diakibatkan oleh hasil erupsi Gunung Merapi, curah hujan, dan erosi sungai. longsor ini menyebabkan kerugian material (angka??), korban jiwa (angka???), kerusakan infrastruktur (angka??), sektor sosial(angka??), ekonomi (angka??)dan mengakibatkan penurunan daya dukung lahan produktif termasuk beberapa kawasan permukiman, pariwisata, budidaya dan lindung yang ditetapkan sebagai kawasan strategis nasional. Untuk meminimasi dampak longsor tersebut, stakeholders memiliki tindakan adaptasi berupa bla... bla... . Adaptasi saat ini dirasakan kurang efektif mengingat kejadian longsor dan dampaknya tetap terjadi. Oleh karenanya, penelitian ini berupaya merumuskan arahan adaptasi yang efektif dalam meminimasi dampak longsor di KSN Gunung Merapi

Untuk merumuskan adaptasi yang efektif, penelitian ini memiliki 3 tahapan utama. Pertama, menentukan faktor-faktor yang mempengaruhi kerentanan melalui analisa AHP (analytical hierarchical process ?). kedua, menentukan zona kerentanan melalui weighted overlay berdasarkan bobot faktor dari AHP. Ketiga, merumuskan pola adaptasi pada daerah yang memiliki kerentanan yang tinggi melalui analisa ......?

Berdasarkan hasil analisa, Kecamatan Kalasan adalah kecamatan berzona kerentanan tertinggi. Faktor dominan kerentanan di kecamatan tersebut adalah supply kebutuhan air berdasarkan jarak potensi longsor yang dekat dengan sungai, tingkat kepadatan bangunan, persentase laju pertumbuhan penduduk, tingginya jumlah usia tua-balita, dan jenis tumbuhan yang menutupi lereng. Berdasarkan faktor dominan tersebut, rumusan adaptasi untuk Kecamatan Kalasan terbagi dalam 4 fase disaster risk management. Fase mitigasi dilakukan pembuatan saluran drainase pada tebing sungai yang rawan tanah longsor seperti Cangkringan dan Pakem yang melalui Kecamatan Kalasan. Fase kesiapsiagaan difokuskan dengan melakukan antisipasi kondisi cuaca diwilayah Kecamatan Kalasan dan sekitarnya pada akhir musim kemarau dan awal musim penghujan secara realtime berbasis seluler yang dipancarkan ke BMKG setempat. Fase respon difokuskan pada penyediaan peralatan medis dan bantuan relawan sebagai tanggap darurat pertama kepada masyarakat di sekitaran Kecamatan Kalasan dan wilayah lainnya. Dan, fase pemulihan dilakukan dengan mengembalikan kondisi sosial ekonomi dan budaya masyarakat di Kecamatan Kalasan dan sekitarnya yang terkena tanah longsor.
\end{abstract}

Kata Kunci: adaptasi, bencana longsor, kerentanan 


\section{PENDAHULUAN}

Kabupaten Sleman merupakan salah satu Kabupaten di Provinsi DIY yang termasuk dalam Kabupaten dengan tingkat kerawanan bencana tanah longsor yang besar. Kondisi ini dilihat dari pegunungan dan perbukitan di Kabupaten Sleman seluas $72,11 \%$ dari luas wilayah keseluruhan (RTRW Kabupaten Sleman, 2011-2031). Fakta menununjukkan Kabupaten Sleman memiliki ketinggian antara 100-2.500 meter dpl, dengan kemiringan yang sangat curam diatas $>40 \%$ seluas $1.526 \mathrm{~km}^{2}$ dengan total wilayah mencapai 27.081 ha. [1]

Salah satu penyebab terjadinya rawan tanah longsor yaitu pada permasalahan lingkungan dan sosial yang menonjol seperti pertanian intensif, kerusakan hutan atau luasnya lahan kritis di Kabupaten Sleman yang mencapai 3.225,74 ha dengan tingkat curah hujan tahunan diatas $2000 \mathrm{~mm}$ pertahun. Hal ini mengakibatkan tidak adanya tutupan tanah yang membentuk ruang-ruang dalam tanah akibat pembusukan sistem perakaran pohon yang menampung air dan menyebabkan tanah dalam keadaan lewat jenuh, sehingga berpotensi longsor. [2]

Bencana longsor di Kabupaten Sleman yang terjadi tahun 2011 sebanyak 34 unit rumah tertimbun, korban jiwa 4 orang, dengan luasan kawasan rawan longsor mencapai kurang lebih 3.303 ha pada Kecamatan Prambanan dan Berbah, 23 ha di Kecamatan Turi, 9 ha di Kecamatan Pakem, dan Kecamatan lainnya yang memiliki tingkat kerentanan sedang dan lebih rendah. Pada tahun 2012 kerusakan yang terjadi sebesar 40 unit rumah, 3 korban meninggal, $1 \mathrm{~km} / \mathrm{unit}$ jalan lingkungan dan $2 \mathrm{~km} / \mathrm{unit}$ jalan desa di Kecamatan Pakem, 1 unit jembatan desa di Kecamatang Cangkringan, irigasi di sungai Opak desa Bokoharjo seluas 273,37 ha, 1 unit pipa transmisi di Kecamatan Kalasan-Prambanan, kerusakan sektor pertanian di Pakem 21 ha dan 35 ha di Kecamatan Cangkringan, 1 jalur trekking dan kawasan outbond tertimbun di desa wisata Kecamatan Pakem, kawasan lingkungan wisata Candi Ratu Boko di Kecamatan Prambanan, dan camping ground seluas 3 ha di desa Glagaharjo. [3]

Dampak bencana tanah longsor di Kabupaten Sleman berbanding terbalik dengan potensi wilayah ini sebagai kabupaten dengan penyumbang PDRB tertinggi pada sektor pariwisata. Sektor pariwisata di Kabupaten Sleman memberikan kontribusi $\pm 35 \%$ dari total pendapatan sektor pariwisata di Provinsi DIY, dengan total pendapatan mencapai Rp 31.699.102.015 rupiah. Kondisi dari dampak tanah longsor ini berakibat pada rusaknya lahan-lahan pariwisata dan lahan produktif lainnya di wilayah penelitian.[4]

Berangkat dari masalah kerentanan tanah longsor yang dihadapi masyarakat di Kabupaten Sleman maka studi ini secara komprehensif meneliti faktor-faktor yang mempengaruhi tingkat kerentanan masyarakat terhadap tanah longsor, penentuan zona tingkat kerentanan masyarakat terhadap tanah longsor dan pola adaptasi kawasan rawan tanah longsor berdasarkan zona sangat rentan sebagai upaya pengendalian kerentanan tanah longsor di KSN Gunung Merapi Kabupaten Sleman.

\section{METODE}

II.1 Metode Pengumpulan Data

Dalam pengumpulan data, dilakukan survey primer dan survey sekunder. Survei primer terdiri dari observasi langsung ke wilayah penelitian (foto kondisi eksisting) dan wawancara (wawancara stakeholders, yang mana telah didapatkan beberapa stakeholders untuk wawancara yang didapatkan melalui analisis stakeholders. Stakeholder yang digunakan dalam penelitian ini dibagi menjadi dua bagian untuk responden dalam analisa AHP (Bappeda, BPBD, ESDM, Dinas PU Cipta Karya, Ahli kebencanaan, Praktisi (PT.Studio Cilaki Empat Lima), Koperasi UPT susu, UKM pengrajin batu, Pengelola Candi Prambanan, dan tokoh masyarakat ), 
dan responden untuk analisa Triangulasi (Bappeda, BPBD, ESDM, Dinas PU Cipta Karya, Koperasi UPT susu, dan tokoh masyarakat).

Survei sekunder terdiri dari survey instansi dan survey literatur. Survei instansi merupakan survei yang dilakukan dalam mengumpulkan data sekunder atau pendukung di instansi atau dinas-dinas. Studi literatur atau kepustakaan dilakukan dengan meninjau isi dari literatur yang bersangkutan dengan tema penelitian ini, di antaranya berupa buku, hasil penelitian, dokumen rencana tata ruang, tugas akhir, serta artikel di internet dan media massa

\section{II.2 Metode Analisis}

Untuk mengidentifikasi kawasan rentan tanah longsor di KSN Gunung Merapi Kabupaten Sleman maka diperlukan beberapa tahapan analisis, adapun tahapan analisis dalam penelitian ini yaitu; menganalisa faktor-faktor yang mempengaruhi tingkat kerentanan masyarakat terhadap tanah longsor dalam KSN Gunung Merapi di Kabupaten Sleman dengan analisa deskriptif, menentukan zona tingkat kerentanan masyarakat terhadap tanah longsor dalam KSN Gunung Merapi di Kabupaten Sleman dengan overlay weighted slum analysis, dan terakhir dengan merumuskan arahan adaptasi kawasan rawan tanah longsor berdasarkan tingkat kerentanan masyarakatnya di zona sangat rentan dalam KSN Gunung Merapi Kabupaten Sleman melalui metode analisis triangulasi.

\section{HASIL}

\section{Analisa faktor-faktor mempengaruhi tingkat kerentanan masyarakat terhadap tanah longsor}

Berdasarkan tahapan analisis deskriptif, faktor mempengaruhi tingkat kerentanan masyarakat terhadap tanah longsor pada Tabel 1.Berikut tabel faktor-faktor yang mempengaruhi tingkat kerentanan masyarakat terhadap tanah longsor.
Tabel 1

Faktor-Faktor yang Mempengaruhi

Tingkat Kerentanan Masyarakat terhadap Tanah Longsor

\begin{tabular}{|c|c|}
\hline Faktor & $\begin{array}{l}\text { Parameter Penilaian } \\
\text { Kerentanan Longsor }\end{array}$ \\
\hline \multicolumn{2}{|c|}{ Kerentanan Lingkungan } \\
\hline $\begin{array}{l}\quad \text { Jenis tumbuhan } \\
\text { yang menutupi } \\
\text { lereng dikawasan } \\
\text { rawan tanah } \\
\text { longsor } \\
\end{array}$ & $\begin{array}{l}\text { Semakin tinggi tutupan } \\
\text { lahan yang dialih fungsi } \\
\text { untuk kegiatan budidaya } \\
\text { maka semakin rentan } \\
\text { terhadap tanah longsor }\end{array}$ \\
\hline $\begin{array}{l}\quad \text { Supply } \\
\text { kebutuhan air } \\
\text { berdasarkan jarak } \\
\text { potensi longsor } \\
\text { yang dekat dengan } \\
\text { sungai }\end{array}$ & \begin{tabular}{l}
\multicolumn{1}{c}{ Semaikin dekat jarak } \\
tanah longsor dengan \\
sungai maka semakin \\
rentan kualitas supply \\
kebutuhan airnya yang \\
terkena tanah longsor.
\end{tabular} \\
\hline \multicolumn{2}{|c|}{ Kerentanan Fisik } \\
\hline \begin{tabular}{l}
\multicolumn{1}{c}{ Tingkat } \\
kepadatan \\
bangunan di \\
wilayah rawan \\
tanah longsor \\
\end{tabular} & $\begin{array}{l}\text { Semakin tinggi tingkat } \\
\text { kepadatan bangunan maka } \\
\text { semakin rentan terhadap } \\
\text { tanah longsor }\end{array}$ \\
\hline $\begin{array}{l}\quad \text { Tingkat } \\
\text { distribusi } \\
\text { pelayanan jaringan } \\
\text { listrik yang berada } \\
\text { dilereng kawasan } \\
\text { longsor }\end{array}$ & $\begin{array}{l}\quad \text { Semakin banyak titik } \\
\text { jaringan listrik yang } \\
\text { berdekatan dengan kawasan } \\
\text { rawan longsor, maka } \\
\text { semakin rentan terhadap } \\
\text { tanah longsor }\end{array}$ \\
\hline $\begin{array}{l}\quad \text { Panjang jalan } \\
\text { yang } \\
\text { rusak/tertimbun } \\
\text { tanah longsor }\end{array}$ & $\begin{array}{l}\text { Semakin rendah } \\
\text { ketersediaan jalan, maka } \\
\text { semakin rentan terhadap } \\
\text { tanah longsor }\end{array}$ \\
\hline \multicolumn{2}{|c|}{ Kerentanan Sosial } \\
\hline \begin{tabular}{l}
\multicolumn{1}{c}{ Tingkat } \\
kepadatan \\
penduduk dilokasi \\
rawan longsor
\end{tabular} & $\begin{array}{l}\text { Semakin besar kepadatan } \\
\text { penduduk, maka semakin } \\
\text { rentan terhadap tanah } \\
\text { longsor }\end{array}$ \\
\hline \begin{tabular}{l}
\multicolumn{1}{c}{ Tingginya } \\
persentase laju \\
pertumbuhan \\
Penduduk di lokasi \\
rawan longsor \\
\end{tabular} & \begin{tabular}{l}
\multicolumn{1}{c}{ Semakin tinggi laju } \\
pertumbuhan penduduk tiap \\
kecamatan maka semakin \\
rentan terhadap tanah \\
longsor
\end{tabular} \\
\hline \begin{tabular}{l}
\multicolumn{1}{c}{ Tingginya } \\
jumlah penduduk \\
usia tua-balita
\end{tabular} & $\begin{array}{l}\text { Semakin banyak jumlah } \\
\text { penduduk usia tua-balita } \\
\text { tiap kecamatan maka } \\
\text { semakin rentan terhadap } \\
\text { tanah longsor }\end{array}$ \\
\hline \multicolumn{2}{|c|}{ Kerentanan Ekonomi } \\
\hline \begin{tabular}{l}
\multicolumn{1}{c}{ Tingginya } \\
persentase rumah \\
tangga yang
\end{tabular} & $\begin{array}{l}\text { Semakin besar } \\
\text { persentase rumah tangga } \\
\text { yang bekerja di sektor } \\
\text { rentan (pertanian) maka }\end{array}$ \\
\hline
\end{tabular}




\begin{tabular}{|l|l|}
\hline \multicolumn{1}{|c|}{ Faktor } & \multicolumn{1}{c|}{$\begin{array}{c}\text { Parameter Penilaian } \\
\text { Kerentanan Longsor }\end{array}$} \\
\hline $\begin{array}{l}\text { bekerja di sektor } \\
\text { rentan (petani) }\end{array}$ & $\begin{array}{l}\text { semakin rentan terhadap } \\
\text { tanah longsor }\end{array}$ \\
\hline $\begin{array}{l}\text { Tingginya } \\
\text { persentase rumah } \\
\text { tangga miskin yang } \\
\text { berada disekitar } \\
\text { kawasan rawan } \\
\text { longsor }\end{array}$ & $\begin{array}{l}\text { Semakin besar } \\
\text { persentase rumah miskin } \\
\text { maka semakin tinggi } \\
\text { tingkat kerentanan terhadap } \\
\text { tanah longsor. }\end{array}$ \\
\hline
\end{tabular}

Hasil analisis 2013

Beri penjelasan terkait dengan tabel 1 di atas.

\section{Analisa bobot faktor-faktor yang mempengaruhi tingkat kerentanan masyarakat terhadap tanah longsor}

Dari tabel diatas diketahui bahwa faktor-faktor yang berpengaruh/prioritas dalam penentuan tingkat kerentanan terhadap masyarakat dilokasi rentan tanah longsor berdasarkan hasil perhitungan bobot AHP dan kepentingan analisa stakeholder adalah sebagai berikut:

1. Jenis tumbuhan yang menutupi lereng dengan bobot $(0,565)$

2. Tingginya persentase rumah tangga miskin dengan bobot $(0,515)$

3. Tingginya persentase rumah tangga yang bekerja disektor rentan (petani) dengan bobot $(0,485)$

4. Supply kebutuhan air berdasarkan jarak potensi longsor yang dekat dengan sungai (bobot 0,435 )

5. Tingkat kepadatan bangunan dengan bobot $(0,416)$

6. Tingginya jumlah penduduk usia tua-balita dengan bobot $(0,406)$

7. Tingginya kepadatan penduduk dengan bobot $(0,317)$

8. Panjang jalan yang rusak/tertimbun tanah longsor $(0,307)$

9. Tingginya persentase laju pertumbuhan penduduk denga bobot $(0,277)$

10. Tingkat distribusi pelayanan jaringan listrik dengan bobot $(0,277)$

\section{Penentuan zona tingkat kerentanan masyarakat terhadap tanah longsor}

Berdasarkan hasil analisa overlay weighted sum di wilayah penelitian didapat zona sangat rentan dan tidak rentan pada masing-masing kerentanan (kerentanan lingkungan, kerentanan fisik, kerentanan sosial, kerentanan ekonomi) yang dihasilkan dari faktor-faktor yang mempengaruhi masing-masing kerentanan.

a. Kerentanan Lingkungan dengan zona sangat rentan berada di Kecamatan Cangkringan (luas kerentanan 4.799 ha), dan zona tidak rentan di Kecamatan Prambanan dengan luas kerentanan 4.135 ha

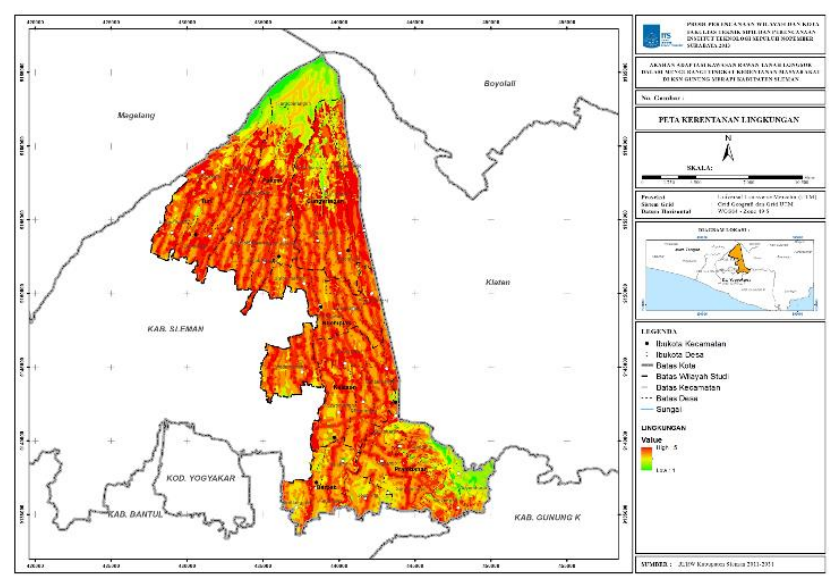

Gambar 1. Peta Kerentanan Lingkungan

b. Kerentanan Fisik dengan zona sangat rentan berada di Kecamatan Kalasan dengan luas kerentanan 3.584 ha, zona tidak rentan berada di Kecamatan Turi dengan luas 4.309 ha dan Kecamatan Cangkringan dan Pakem dengan luas 9.183 ha. 


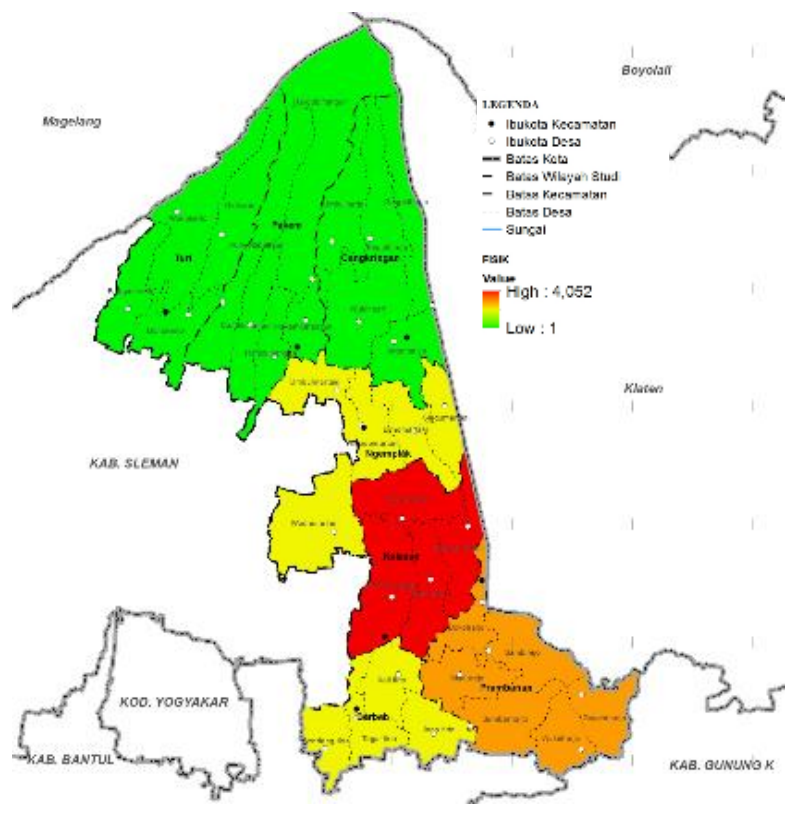

Gambar 2. Peta Kerentanan Fisik

c. Kerentanan Sosial dengan zona sangat rentan berada di Kecamatan Kalasan dengan luas kerentanan 3.584 ha dan zona tidak rentan berada di Kecamatan Cangkringan, Turi dan Pramabanan dengan luas kerentanan 13.492 ha.

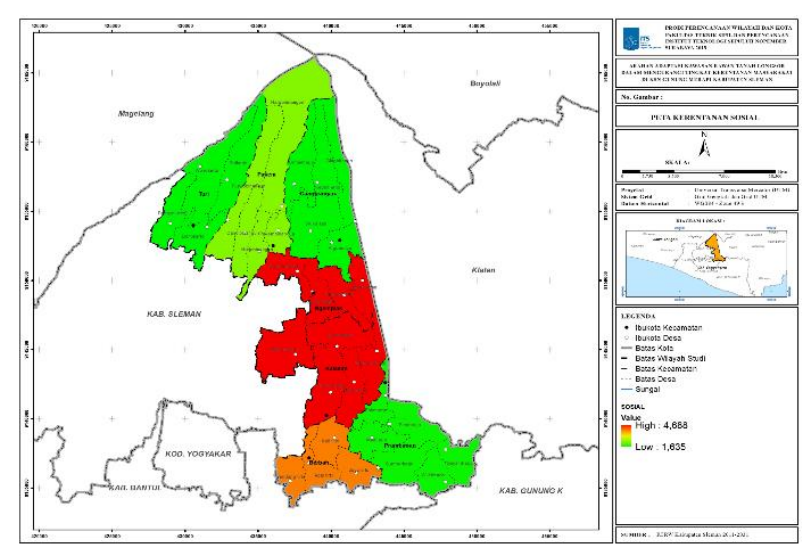

Gambar 3. Peta Kerentanan Sosial

d. Kerentanan Ekonomi dengan zona sangat rentan berada di Kecamatan Cangkringan (luas kerentanan 4.799 ha), Kecamatan Turi dan Pakem dengan luas kerentanan 8.693 ha, sedangkan zona tidak rentan berada di Kecamatan Kalasan dengan luas kerentanan 3.584 ha dan Kecamatan Berbah dengan luas kerentanan 2.299 ha.

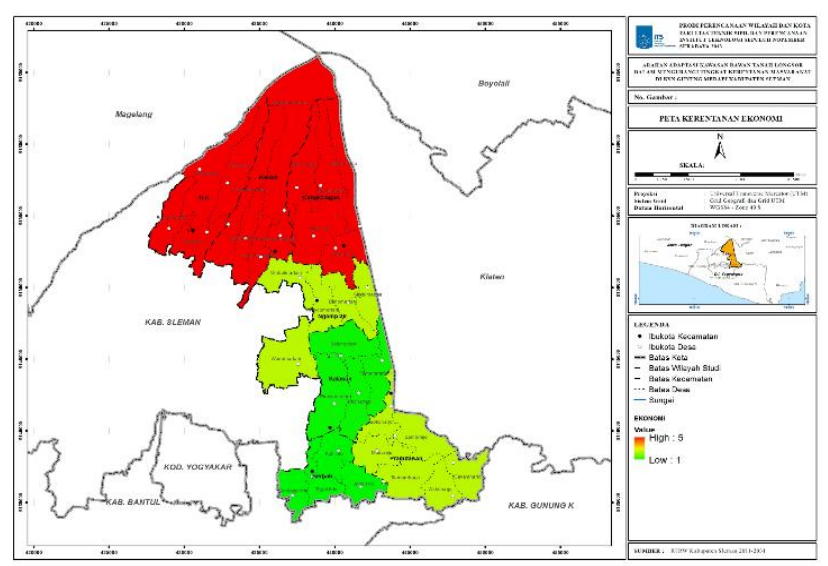

Gambar 4. Peta Kerentanan

Ekonomi

Berdasarkan hasil overlay kerentanan total wilayah penelitian diperoleh zona sangat rentan berada di Kecamatan Kalasan dengan luas kerentanan 26,76 $\mathrm{km}^{2}$ dari total wilayah penelitian $274,1125 \mathrm{~km}^{2}$. Sedangkan zona tidak rentan berada di Kecamatan Turi dengan luas kerentan 4.309 ha.

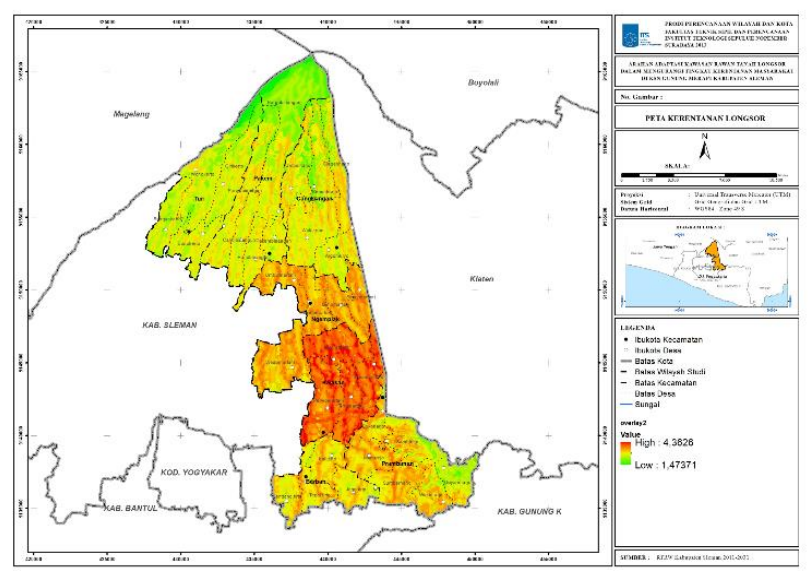

Gambar 5.

Peta Kerentanan Total

Perumusan arahan adaptasi kawasan rawan longsor berdasarkan tingkat kerentanan masyarakat di zona sangat rentan dalam KSN Gunung Merapi Kabuapten Sleman

Jelaskan kenapa perumusan adaptasi ini perlu melihat faktor kerentanan. Lihat paper saya dan mestinya sudah ada di TA mba deas.

Perumusan arahan adaptasi kawasan rawan tanah longsor ini berdasarkan hasil 
tahapan sebelumnya yaitu dengan proses GIS dalam menentukan zona sangat rentan dalam kawasan rawan tanah longsor di KSN Gunung Merapi Kabupaten Sleman. Dengan zona sangat rentan berada di Kecamatan Kalasan. Dari hasil penentuan zona sangat rentan tersebut terdapat beberapa faktor yang dominan dan mempengaruhi Kecamatan Kalasan sebagai daerah dengan zona sangat rentan. Adapun Faktor yang mempengaruhi tersebut yaitu:

a. Supply kebutuhan air berdasarkan jarak potensi longsor yang dekat dengan sungai.

b. Tingkat kepadatan bangunan

c. Persentase laju pertumbuhan penduduk

d. Tingginya jumlah usia tua-balita

e. Jenis tumbuhan yang menutupi lereng.

Dari hasil faktor yang dominan tersebut maka dapat dirumuskan pola adaptasi zona sangat rentan kawasan rawan tanah longsor di Kecamatan Kalasan berdasarkan klasifikasi fase pola adaptasi (fase mitigasi, fase kesiapsiagaan, fase respon, dan fase pemulihan).

Adapun arahan yang dihasilkan pada masing-masing fase pola adaptasi yaitu:

fase mitigasi

dengan membuat saluran drainase pada tebing sungai yang rawan tanah longsor dari wilayah atas seperti Cangkringan dan Pakem yang melalui Kecamatan Kalasan,

fase kesiapsiagaan

yaitu dengan melakukan antisipasi kondisi cuaca diwilayah Kecamatan Kalasan dan sekitarnya pada akhir musim kemarau dan awal musim penghujan secara realtime berbasis seluler yang dipancarkan ke BMKG setempat,

fase respon

dengan menyediakan peralatan medis dan bantuan relawan sebagai tanggap darurat pertama kepada masyarakat di sekitaran Kecamatan Kalasan dan wilayah lainnya, dan

\begin{abstract}
fase pemulihan
dengan mengembalikan kondisi sosial ekonomi dan budaya masyarakat di Kecamatan Kalasan dan sekitarnya yang terkena tanah longsor.
\end{abstract}

\section{PEMBAHASAN}

\section{Menganalisa faktor-faktor yang mempengaruhi tingkat kerentanan masyarakat terhadap tanah longsor}

Faktor-faktor yang berpengaruh terhadap kerentanan masyarakat pada kawasan rawan tanah longsor ditinjau dari teori-teori terkait kerentanan longsor berdasarkan kerentanan lingkungan, fisik, sosial dan ekonomi. Dalam analisa faktorfaktor yang mempengaruhi tingkat kerentanan masyarakat terhadap tanah longsor digunakan analisis deskriptif dan analisis AHP yang melakukan perhitungan dengan tingkat kepentingan pada analisa stakeholdernya. Analisis deskriptif mendeskripsikan mengenai faktor-faktor yang mempengaruhi tingkat kerentanan masyarakat terhadap tanah longsor berdasarkan teori, kebijakan dan kondisi eksistingnya. [5]

Analisis AHP digunakan untuk menentukan bobot tiap faktor yang berpengaruh terhadap kerentanan, dalam analisis digunakan alat analisis expert choice. Hasil proses analisis AHP digunakan untuk melakukan perhitungan antara bobot masing-masing faktor dengan tingkat kepentingan masing-masing stakeholder. Sehingga menghasilkan faktor-faktor yang mempengaruhi kerentanan masyarakat berdasarkan tingkat kepentingan stakeholdernya. [6]

\section{Penentuan zona tingkat kerentanan masyarakat terhadap tanah longsor}

Teknik analisa yang digunakan untuk memperoleh zona tingkat kerentanan masyarakat terhadap tanah longsor berdasarkan tingkat kerentanannya adalah menggunakan teknik overlay weighted sum beberapa peta/faktor yang berpengaruh 
terhadap kerentanan. Metode analisis ini merupakan analisis spasial dengan menggunakan teknik overlay beberapa peta yang berkaitan dengan faktor-faktor yang berpengaruh terhadap penilaian kerentanan. Alat analisis yang digunakan adalah dengan menggunakan Geographic Information System (GIS). Proses analisa dengan GIS ini menghasilkan zona tidak rentan dan sangat rentan pada overlay masing-masing faktor. [7]

\section{Perumusan arahan adaptasi kawasan rawan longsor berdasarkan tingkat kerentanan masyarakat di zona sangat rentan dalam KSN Gunung Merapi Kabuapten Sleman}

Arahan adaptasi kawasan rawan longsor ini untuk mengetahui pola adaptasi yang efektif untuk kawasan rawan longsor dengan tingkat kerentanan masyarakatnya pada zona sangat rentan.

Dalam analisis arahan adaptasi kawasan rawan longsor pada zona sangat rentan ini, yaitu analisa triangulasi. Tahapan pertama dengan melakukan analisa deskriptif dengan mengkomparasikan sintesa tinjauan pustaka variabel pola adaptasi kerentanan masyarakat yang berasal dari teori/kondisi eksisting dan standar/kebijakan dengan masing-masing faktor kerentanan yang paling dominan/prioritas di lokasi zona sangat rentan. Analisa deskriptif ini menjadi hasil penelitian untuk sumber informasi dalam menganalisa triangulasi.

Tahapan kedua menggunakan analisa triangulasi yang bertujuan untuk merumuskan pola adaptasi yang efektif untuk pola ruang di zona sangat rentan. Analisa triangulasi pada dasarnya menggunakan 3 sumber data yang berasal dari pakar kompeten yaitu pakar-pakar ahli yang telah dipilih berdasarkan analisa stakeholder.

Tiga sumber data tersebut meliputi; pendapat stakeholders mengenai pola adaptasi yang efektif untuk mengurangi tingkat kerentanan masyarakat di zona sangat rentan tanah longsor, selain pendapat stakeholders sumber infomasinya juga berasal dari studi literatur/kebijakan mengenai arahan adaptasi kawasan rawan tanah longsor serta dari hasil penelitian yang berdasarkan hasil pembahasan yang telah dilakukan peneliti dari berbagai sumber teori dan data eksisting.

\section{KESIMPULAN DAN SARAN}

Berdasarkan hasil analisis di dalam penelitian ini dapat disimpulkan bahwa faktor-faktor berpengaruh terhadap tingkat kerentanan masyarakat dilokasi rawan tanah longsor yaitu: faktor jenis tumbuhan yang menutupi lereng, faktor supply kebutuhan air berdasarkan jarak titik longsor yang dekat dengan sungai, faktor tingkat kepadatan bangunan, faktor panjang jalan yang rusak/tertimbun tanah longsor, tingkat distribusi pelayanan jaringan listrik di kawasan rawan longsor, tingkat kepadatan penduduk dilokasi longsor, tingginya persentase laju pertumbuhan penduduk dilokasi longsor, tingginya jumlah penduduk usia tua-balita, tingginya persentase rumah tangga bekerja disektor rentan, dan tingginya persentase rumah tangga miskin

Dari hasil faktor tersebut didapatkan zona kerentanan tanah longsor di kabupaten Sleman pada zona sangat rentan berada di Kecamatan Kalasan luas kerentanan 26,76 $\mathrm{km}^{2}$ dari total wilayah penelitian 274,1125 $\mathrm{km}^{2}$. Sedangakan zona kerentanan lingkungan dengan zona sangat rentan berada di Kecamatan Cangkringan (luas kerentanan 4.799 ha), zona kerentanan fisik dengan zona sangat rentan berada di Kecamatan Kalasan dengan luas kerentanan 3.584 ha, zona kerentanan sosial dengan zona sangat rentan berada di

Kecamatan Kalasan dengan luas kerentanan 3.584 ha, dan zona kerentanan ekonomi dengan zona sangat rentan berada di Kecamatan Cangkringan (luas kerentanan 4.799 ha), Kecamatan Turi dan Pakem dengan luas kerentanan 8.693 ha.

Berdasarkan hasil faktor dari penentuan zona sangat rentan yang berada di Kecamatan Kalasan, diperoleh faktorfaktor dominan yang mempengaruhi kecamatan ini menjadi zona sangat rentan 
yaitu; adanya supply kebutuhan air berdasarkan jarak potensi longsor yang dekat dengan sungai, tingkat kepadatan bangunan, persentase laju pertumbuhan penduduk, tingginya jumlah usia tua-balita, dan jenis tumbuhan yang menutupi lereng.

Faktor-faktor dominan ini menghasilkan arahan pola adaptasi berdasarkan empat fasenya yaitu: fase mitigasi dengan membuat saluran drainase pada tebing sungai yang rawan tanah longsor dari wilayah atas seperti Cangkringan dan Pakem yang melalui Kecamatan Kalasan, fase kesiapsiagaan yaitu dengan melakukan antisipasi kondisi cuaca diwilayah Kecamatan Kalasan dan sekitarnya pada akhir musim kemarau dan awal musim penghujan secara realtime berbasis seluler yang dipancarkan ke BMKG setempat, fase respon dengan menyediakan peralatan medis dan bantuan relawan sebagai tanggap darurat pertama kepada masyarakat di sekitaran Kecamatan Kalasan dan wilayah lainnya, dan fase pemulihan dengan mengembalikan kondisi sosial ekonomi dan budaya masyarakat di Kecamatan Kalasan

\section{Daftar Pustaka}

[1] Badan Perencanaan Pembangunan Kabupaten Sleman. 2011. Rencana Tata Ruang Wilayah Kabupaten Sleman 2011-2031. Bappekab Slema : DIY

[2] Departemen Energi dan Sumber Daya Mineral. Pemetaan Resiko Bencana Tanah Longsor Kabupaten Sleman 2010. DESDM: Yogyakarta.

[3] Badan Penanggulangan Bencana Daerah Kabupaten Sleman. 20112012. Laporan Penyusunan Rencana Penanggulangan Bencana. Bappekab Sleman: DIY

[4] Panduan Pengenalan Karakteristik Bencana di Indonesia dan Mitigasinya (2007).

[5] Brikmann, Jorn. Measuring Vulnerability to Natural Hazards:
Towards Disasters Resilient Societies. United Nation University Press. 2006

[6] Saaty, T. L. (1993), Decision Making for Leader: The Analytical Hierarchy Process for Decisions in Complex World. Pittburgh : University of Pittsburgh

[7] IPCC. National Disaster Management Guidelines: Management of Landslides and snow avalnches. Natural Disaster Management. 2001

[8] Marskrey, K 1998. Environmental Hazards: Assesing Risk and Reducing Disaster, Routledge, London

[9] Tolong dimasukkan paper saya kaitannya dengan kenapa adaptasi perlu direview dengan melihat faktor kerentanan nya. Paper saya emailkan sekalian. 